\title{
KOLEGIALITAS KEPEMIMPINAN GURU DALAM PEMBELAJARAN MATEMATIKA SMK
}

\author{
Djalal Fuadi, Eko Rubiyanto, dan A. Fathoni \\ Universitas Muhammadiyah Surakarta \\ Email: ekorubiyanto84@gmail.com
}

\begin{abstract}
This study aimed to describe the collegiality leadership of teachers in mathematics learning in class XI SMK Country 2 Surakarta School Year 2017/2018. This type of research is qualitative research. The subjects of the recipient of the action were students of class XI SMK Country 2 Surakarta 3 classes, namely XI TPM D, XI TKBB, XI TKR A which amounted to 90 students and the subject of the action was the researcher assisted by a mathematics teacher. Method of collecting data through observation, interviews, field notes and documentation. Data analysis techniques were carried out descriptively qualitative with a flow model consisting of date collection, data reduction, data presentation, verification and conclusion drawing. The results of this study indicate that by approaching sis $w$ a private, invite students to dialogue about the future and the dreams that you want, recognize family background da n neighborhood, invite students to improve themselves through faith and piety in synergy den gan science and provides a communication medium in the form $g$ rup online social media to enable students both inside and outside the school can be productive communication so that students succeed in education and future.
\end{abstract}

Keywords: collegiality, teacher, leadership, mathematics

\begin{abstract}
Abstrak. Penelitian ini bertujuan untuk mendeskripsikan kolegialitas kepemimpinan guru dalam pembelajaran matematika kelas XI SMK Negeri 2 Surakarta tahun pelajaran 2017/2018. Jenis penelitian ini adalah penelitian kualitatif. Subjek penerima tindakan adalah siswa kelas XI SMK Negeri 2 Surakarta 3 kelas, yaitu XI TPM D, XI TKBB, XI TKR A yang berjumlah 90 siswa dan subjek pelaksana tindakan adalah peneliti dibantu dengan guru matematika. Metode pengumpulan data melalui observasi, wawancara, catatan lapangan dan dokumentasi. Teknik analisis data dilakukan secara deskriptif kualitatif dengan model alur yang terdiri dari pengumpulan data, reduksi data, penyajian data, verifikasi dan penarikan kesimpulan. Hasil penelitian ini menunjukkan bahwa usaha Collegiality dari guru matematika dalam pembelajaran dengan mendekati siswa secara pribadi, mengajak siswa berdialog tentang masa depan dan impian yang diinginkan, mengenali latar belakang keluarga dan lingkungan tempat tinggalnya, mengajak siswa untuk memperbaiki diri melalui iman dan taqwa yang bersinergi dengan ilmu pengetahuan dan memberikan wadah komunikasi online yang berupa grup media sosial agar siswa baik di dalam maupun di luar sekolah bisa komunikasi produktif agar siswa berhasil dalam pendidikan dan kesuksesan masa depan.
\end{abstract}

Kata kunci: kolegialitas, guru, kepemimpinan, matematika 


\section{Pendahuluan}

Kepemimpinan bukan ditentukan seseorang atau beberapa orang saja, melainkan hasil bersama antara pemimpin dengan yang dipimpin. Kepemimpinan guru tidak akan efektif apabila tidak ada partisipasi siswa. Efektifitas kepemimpinan dikaitkan dengan konsekuensi dan tindakan pemimpin bagi para siswa dan stakeholder. Guru dalam melaksanakan peran sebagai pendidik, pengajar, pemimpin, serta harus mampu melayani peserta didik yang dilandasi dengan kesadaran, keyakinan, kedisiplinan dan tanggung jawab secara optimal sehingga memberikan dampak dan pengaruh positif terhadap perkembangan siswa. Mendidik, mengajar dan melatih siswa adalah tugas guru sebagai profesi. Guru sebagai pendidik berarti meneruskan dan mengembangkan nilai-nilai kehidupan kepada siswa. Fungsi guru sebagai pengajar berarti meneruskan dan mengembangkan ilmu pengetahuan dan teknologi kepada siswa.

Guru harus dapat menempatkan diri sebagai orang tua kedua, dengan mengemban tugas yang dipercayakan orang tua atau wali peserta didik. Guru sebagai pemimpin di kelas harus mampu menciptakan suasana kelas yang nyaman, menyenangkan, dan ilmiah. Guru sebagai pemimpin kelas harus memiliki hati yang bersih, jernih dan menularkan kepada peserta didik agar menjadi baik. Guru sebagai pemimpin kelas harus memiliki kepribadian yang percaya diri, memiliki komitmen yang kuat untuk menjadi manusia yang teguh dengan pendirian. Guru harus membangun kelas sebagai tempat untuk membangun kesejahteraan lahir dan batin sehingga kelas menjadi tempat untuk berbagi dan menyejukan hati secara inovatif. Guru sebagai pemimpin kelas harus power sharing berbagai peran dengan siswa. Guru harus menguasai informasi berbagai ilmu pengetahuan kepada siswa sehingga menjadikan kelas sebagai masyarakat kelas yang memiliki rasa ingin tahu yang tinggi. Guru harus membangun dan menciptakan kelas sebagai tempat untuk memajukan siswa yang intelek, kompetitif dan regeneratif.

Guru sebagai pemimpin kelas harus kompetitif dan menularkan ilmu kepada siswa, baik dari sisi hard skill maupun soft skill dan mewariskan keunggulan kepada siswa sehingga mampu untuk melakukan inovasi, baik secara discovery (menemukan sesuatu yang baru dalam lingkungannya) maupun invention (menemukan sesuatu yang baru dan belum ditemukan ditempat yang lain) sehingga dapat menunjukkan kinerjanya secara unggul, siap untuk bersanding dalam lingkungannya. Kolegialitas sebagai sarana guru dalam berunding dan memecahkan masalah matematika baik antar siswa dan guru. Guru mendiskusikan mata pelajaran, memberi demonstrasi pelajaran dan meninjau serta memberi ulasan pelajaran.

Berbagai usaha sudah dilakukan guru matematika di SMK Negeri 2 Surakarta dalam peningkatan kualitas kepemimpinan pembelajaran, seperti melakukan diskusi antar guru dan diklat pembelajaran matematika. Namun, usaha yang telah dilakukan belum mampu meningkatkan kualitas pembelajaran matematika di kelas. Berdasarkan permasalahan tersebut, guru harus menerapkan kepemimpinan pembelajaran yang efektif yang mampu meningkatkan kualitas pembelajaran. Tujuan dari penelitian ini adalah mendeskripsikan susaha membangun kemampuan komunitas dan memiliki keterampilan komunikasi interaktif (Collegiality) dari guru matematika kelas XI SMK Negeri 2 Surakarta dalam pembelajaran.

\section{Metode Penelitian}

Jenis penelitian ini merupakan penelitian kualitatif karena penelitian ini mendeskripsikan kepemimpinan pembelajaran matematika kelas XI SMK Negeri 2 Surakarta. Penelitian kualitatif adalah penelitian yang berlandaskan pada filsafat postpositivisme, digunakan untuk meneliti pada kondisi objek yang alamiah. Penelitian ini dilaksanakan di SMK Negeri 2 Surakarta di kelas XI Tahun 
Pelajaran 2017/2018 yang beralamatkan di Jalan Adi Sucipto No.33 Surakarta. Penelitian ini dilakukan secara bertahap mulai bulan Januari 2018 sampai selesai yang meliputi tahap persiapan, tahap pelaksanaan, tahap analisis data dan tahap penyusunan laporan.

Data dalam penelitian ini berupa catatan yang disebut fieldnote. Fieldnote terdiri dari dua bagian penting, yaitu bagian deskriptif dan reflektif. Bagian deskripsi dalam fieldnote meliputi potret subjek, rekonstruksi, dialog, deskripsi keadaan fisik tentang tempat dan barang lainnya, serta catatan tentang berbagai peristiwa khusus. Bagian reflektif sebagai kelengkapan deskripsi, fieldnote berisi kalimat dan paragraf yang mencerminkan perhitungan pribadi peneliti mrngrnai berbagai hal yang diteliti. Penelitian ini bersifat kualitatif yang mengambil sumber data primer dan sekunder. Sumber data primer adalah pendidik yang melakukan tindakan dan siswa yang menerima tindakan, sedangkan data sekunder berupa data dokumentasi. Sumber data penelitian ini adalah informan, gejala, fenomena, peristiwa, proses, perilaku,aktivitas, tempat, dan dokumen. Penelitian ini menggunakan teknik snowball sampling yaitu cara pemilihan informan pada waktu di lokasi penelitian, yang kemudian berdasarkan petunjuk informan tersebut peneliti menemukan informasi baru, dan seterusnya berganti informasi lainnya yang tidak terencana sebelumnya sehingga peneliti mendapatkan data yang lengkap dan mendalam.

Pada penelitian kualitatif ini,peneliti hadir sebagi instrumen. Peneliti terlibat langsung atau tidak langsung sebagai instrumen. Peneliti menyiapkan beberapa hal yang diperlukan dalam penelitian tersebut secara lengkap supaya data yang diperoleh valid dan temuannya berkualitas. Strategi pengumpulan data penelitian kualitatif dengan metode interaktif yang meliputi wawancara mendalam dan observasi berperan dan metode non-interaktif meliputi observasi tak berperan, kuesioner, dan mencatat dokumen maupun arsip. Keabsahan dapat dilakukan melalui observasi secara terus menerus, triangulasi sumber, metode, dan peneliti lain, pengecekan anggota, diskusi teman sejawat, dan pengecekan referensi. Penelitian ini dilakukan dengan observasi dan triangulasi data. Triangulasi adalah teknik pemeriksaan keabsahan data yang memanfaatkan sesuatu yang lain di luar data untuk keperluan pengecekan sebagai pembanding terhadap data.

Analisis data dalam penelitian ini dilakukan dengan menggunakan metode alur dimana langkah-langkah yang harus dilalui dalam metode alur meliputi pengumpulan data, penyajian data, dan verifikasi data. Proses analisis data dimulai dengan menelaah seluruh data yang tersedia dari berbagai sumber. Setelah dikaji kemudian membuat rangkuman untuk setiap pertemuan atau tindakan di kelas. Berdasarkan rangkuman yang dibuat kemudian penelitian melaksanakan reduksi data yang kegiatan mencakup unsur-unsur sebagai berikut : (a) memilih data atas dasar relevansi, (b) menyusun data dalam satuansatuan jenis, (c) memokuskan penyederhanaan dan mentransfer dari data kasar ke catatan lapangan. Pada langkah penelitian ini, peneliti berusaha menyusun data yang relevan sehingga dapat menjadi informasi yang dapat disimpulkan dan memiliki makna tertentu. Dengan cara menampilkan data dan membuat hubungan antara variabel, peneliti mengerti apa yang terjadi dan apa yang perlu ditindak lanjuti untuk mencapai tujuan penelitian. Verifikasi data atau penarikan kesimpulan dilakukan secara bertahap untuk memperoleh derajat kepercayaan tinggi. Dengan demikian, analisis data dalam penelitian dilakukan sejak tindakan dilaksanakan. Verifikasi data dilakukan pada setiap tindakan yang pada akhirnya dipadukan menjadi kesimpulan.

\section{Hasil dan Pembahasan}

Membangun komunitas dan memiliki keterampilan komunikasi harus dimiliki oleh seorang guru. Perkembangan potensi akademik siswa harus dipantau secara berkelanjutan sehingga diperlukan kemampuan komunitas dan keterampilan komunikasi interaktif 
agar tidak ada jarak antara siswa dan guru. Kemampuan komunitas pembelajaran matematia terpaku pada kemampuan individu sehingga siswa kurang sosial dalam memecahkan persoalan matematika yang dihadapi. Pengetahuan kurang berkembang sehingga dalam pembelajaran guru perlu adanya komunitas belajar matematika yang dibentuk sesuai dengan prestasi siswa sehingga siswa yang pintar bisa menyalurkan ilmunya ke teman yang pemahaman dan penguasaan materinya kurang memadai. Usaha membangun komunitas dan memiliki keterampilan komunikasi interaktif dengan membentuk komunitas seperti diskusi kelompok, mengajak siswa berdialog, guru mengenali latar belakang dan lingkungan tempat tinggal.

Lingkungan siswa baik di sekolah dan keluarga perlu diperhatikan untuk mengetahui perkembangan akademik maupun potensi siswa. Keluarga merupakan wadah yang sangat penting di antara individu-individu dan merupakan kelompok sosial yang pertama. Untuk itu, kerjasama antara keluarga dan sekolah sangat diperlukan demi masa depan. Usaha membangun komunitas dan memiliki keterampilan komunikasi interaktif dengan memperbaiki diri melalui meningkatkan keimanan dan ketaqwaan melalui pengetahuan yang dimiliki agar apa yang dicita-citakan tercapai. Berdasarkan paparan di atas dapat disimpulkan bahwa usaha guru matematika membangun kemampuan komunitas dan memiliki keterampilan komunikasi interaktif dengan konsultasi pendidikan baik kompetensi dan masa depan secara online dan offline serta mengajaak siswa untuk memperbaiki diri melalui keimanan dan ketaqwaan melalui pengetahuan yang dimiliki agar siswa tidak salah melangkah menuju cita-cita yang diharapkan.

Hasil temuan penelitian usaha membangun komunitas dan memiliki keterampilan komunikasi interaktif adalah dengan pendekatan secara pribadi maupun kelompok, memahami karakter siswa, mengajak siswa berdialog, mengenali latar belakang keluarga dan lingkungan dan memperbaiki keimanan dan ketaqwaan baik secara offline maupun online. Jarmila Robova (2013) dalam penelitiannya menyatakan bahwa penggunaan teknologi modern yang semakin luas memusatkan perhatian pada dampak internet terhadap pengetahuan dan keterampilan guru dan siswa belum disediakan. National Mathematics Advisory Panel (2008) menyatakan bahwa guru menggunakan situs web dan media sosial yang berkualitas di kelas, kemungkinan besar mereka akan mencari tahu setelah jangka waktu tertentu. Ini maknanya situs web dan media sosial bagaimanapun dapat memberi tahu para guru untuk memotivasi dan menarik siswa, meningkatkan kejelasan dan termasuk metode proaktif di kelas mereka. Guru menggunakan media online, literatur, dan internet agar tidak kepemimpinan guru matematika sanat diperlukan usaha membangun kemampuan komunitas dan keterampilan komunikasi interaktif.

Komunikasiinteraktifdalampembelajaran matematika merupakan kekuatan sentral bagi siswa dalam merumuskan konsep dan strategi matematika, sebagai modal keberhasilan siswa terhadap pendekatan dan penyelesaian dalam eksplorasi dan investigasi matematika, dan komunikasi sebagai wadah bagi siswa untuk memperoleh informasi atau membagi pikiran, menilai dan mempertajam ide untuk meyakinkan orang lain. Kolegialitas mengacu pada hubungan antara komunitas kelas yang didasarkan atas penghargaan terhadap kemampuan satu sama lain yaitu, antara siswa dan guru dengan tujuan bersama dalam peningkatan kualitas pendidikan. Menurut pendapat Sanjaya (2017) menyatakan bahwa proses komunikasi dalam pembelajaran matematika sebaiknya terjadi multi arah, yakni komunikasi yang terjadi baik antara guru dan siswa, siswa dan siswa maupun siswa dan lingkungan. Maknanya bahwa pembelajaran matematika yang dilaksanakan di kelas merupakan proses komunikasi. Selain usaha membangun komunikasi interaktif di dalam kelas guru matematika SMK N 2 Surakarta 
juga membangun kemampuan komunitas dengan cara membentuk diskusi kelompok belajar dan diskusi konsultasi via online denga Grup WhatShapp secara online yang isinya sharing antara siswa dan guru matematika di luar sekolah tentang permasalahan matematika sehingga terjalin komunikasi yang produktif.

\section{Penutup}

Usaha membangun kemampuan komunitas dan memiliki keterampilan komunikasi interaktif dari guru matematika kelas XI SMK Negeri 2 Surakarta dalam pembelajaran adalah guru mendekati siswa secara pribadi (tes tertulis) maupun kelompok (diskusi), mengajak siswa berdialog tentang masa depan dan impian yang diinginkan, mengenali latar belakang keluarga dan lingkungan tempat tinggalnya. Guru mengajak siswa untuk memperbaiki diri melalui iman dan taqwa yang bersinergi dengan ilmu pengetahuan agar siswa tidak salah langkah dalam meraih cita-cita yang diinginkan. Guru memberikan wadah komunikasi online yang berupa Grup media sosial agar siswa baik di dalam maupun di luar sekolah bisa komunikasi produktif agar siswa berhasil dalam pendidikan dan kesuksesn masa depan. Berbagai ucapan terima kasih kami sampaikan kepada berbagai pihak yang telah mendukung kegiatan penelitian ini. Ucapan terima kasih kami sampaikan kepada Direktorat Riset dan Pengabdian Masyarakat Direktorat Jenderal penguatan Riset dan Pengembangan Kementerian Riset, Teknologi, dan Pendidikan Tinggi yang telah membantu dalam pendanaan biaya penelitian multi tahun melalui Hibah Penelitian Tim Pascasarjana. Ucapan terima kasih kami sampaikan kepada Direktur Sekolah Pascasarjana dan Ketua Lembaga Penelitian UMS beserta stafnya, yang telah memberikan fasilitas dan dorongan sehingga kami bisa melakukan penelitian. Ucapan terima kasih juga kami sampaikan kepada kepala Dinas Pendidikan, kepala dan guru matematika SMK Negeri 2 Surakarta, yang telah membantu proses penelitian sehingga berjalan sesuai perencanaan.

\section{Daftar Pustaka}

Abdul Azis, Hamka. 2012. Karakter Guru Profesional. Jakarta ; Al Mawardi Prima

Ahmadi.2007.Sosiologi Pendidikan.Jakarta : Rineka Cipta

Anastasiadou, Sofia D.2014. Students' toward effective leadership in education. Elsevier Science Direct Procedia Social and Behavioral Sciences 143 : 941-946

Androniceanu,Armenia. 2015. Leadership Competecies for Project Based School Management Succes. Elsevier Science Direct Procedia Social and Behavioral Sciences 182 : 232-238

Assoc. Prof.DR.Amalija Zakelj.2014. Support to Pupils with Learning Difficulties in Mathematics. Elsevier Science Direct Procedia Social and Behavioral Sciences 159 : 506-511

Bambang Sumardjoko. 2015. Metodologi Penelitian Kualitatif.Surakarta : UMS

Edward Sallis. 2011.Total Quality Management in Education. Yogyakarta: IRCisoD

Ibrahim,Mohd Yusril.2015. Model of Virtual Leadership, Intra-Team Communication and Job Performance Among School Leaders in Malaysia. Elsevier Science Direct Procedia Social and Behavioral Sciences 186 : 674-680

Karaduman,Gulsah Batdal.2015. Investigation of The Relationship Between Study Approaches and Self-Regulated Learning Skills of Teacher Candidates. Elsevier Science Direct Procedia Social and Behavioral Sciences 174 : 251-258

Mundia,Lawrence. 2015. Factors Contribusing to Effective Mathematics Teaching in Secondary 
Schools in Brunei Darusalam. Elsevier Science Direct Procedia Social and Behavioral Sciences $186: 474-481$

Oros,Cosmin.2015. Mathematical Education-Improving Methods for High School Terminal Classes. Elsevier Science Direct Procedia Social and Behavioral Sciences 191 : 15381543

Richardson,Lystra M.2015. Making Learning Foundational in Developing School Leaders. Elsevier Science Direct Procedia Social and Behavioral Sciences 174 : 2069-2074

Robova,Jarmila.2013. The Impact of Web Sites on Teaching and Learning Mathematics. Elsevier Science Direct Procedia Social and Behavioral Sciences 186 : 474-481

Sanjaya.2017.Paradigma Baru Mengajar.Jakarta : Kencana

Sah,Madiha.2012. The importnce and benefits of teacher collegelity in schools. Elsevier

Science Direct Procedia Social and Behavioral Sciences : 1242-1246

Siew Kheng Chua,Catherine.2015.Teacher Leadership enactment in profesional learning communiy contexts: Towards a better understanding of the phenomenon. School Leadership and Management, 35(2), 163 - 182.

Sofyan Anif.2014.Profesi Guru Antara Konsep, Implementasi, dan Pembinaan.Surakarta : BPFKIP UMS

Syamsul Bahri.2010. Strategi Belajar Mengajar. Jakarta : Rineka Cipta

Taniredja,Tukiran.2016. Guru yang Profesional. Bandung : Alfabeta

Tezer,Murat.2015.Determining Atittudes and anxiety Levels of Students in Need of Proctetion Towards Mathematics Course. Elsevier Science Direct Procedia Social and Behavioral Sciences $186: 269-273$

Thinwiangthong,Sampan.2014.Pre- and In-Service Teacher' Role to Improve the Teaching and Learning Mathematics. Elsevier Science Direct Procedia Social and Behavioral Sciences $116: 1940-1944$

Tim Tarver. 2015. The Retention Rate of Students of Mathematics Education. Elsevier Science Direct Procedia Social and Behavioral Sciences 186 : 256- 259.

Tim Penyusun.2017. Pedoman Penulisan Tesis. Surakarta : SPs UMS

Tim Penyusun. 2018.Teknik Penulisan Ilmiah Menggunakan Smart Word dan Management Reference.Surakarta : Laboratorium SPs UMS

Yilmazer,Gulcin.2014. This Relationship Between Secondary School Students' Arithmetic Performance and Their Mathematical Literacy. Elsevier Science Direct Procedia Social and Behavioral Sciences $152: 619-623$ 